\title{
Organizing at Walmart: Lessons from Quebec's Women ${ }^{1}$
}

\author{
Stéphanie Mayer, Laval University, Canada \\ Yanick Noiseux, University of Montreal, Canada
}

\begin{abstract}
The job market has undergone fundamental changes over the last thirty years. The decline in permanent, stable, full-time employment and an increase in the number of non-standard workers transformed workers' collective organization and union representation. Based on a study of the collective struggles of women employed at Walmart in Quebec and taking into consideration the interrelated effects of non-standard workers' work and living conditions, the paper explores the ways in which organized labour can adapt to the new context. Two types of data were used: newspapers and academic literature and the results of a study in which eleven women working at Walmart were interviewed between 2010 and 2012. This case study is divided into three parts. In the context of the tertiarization of Quebec's employment market, the effects of the flexibilization of labour at Walmart are first presented through statistical evidence and the comments of the women interviewed. The next section provides an overview of the UFCW's union battles with Walmart, including some of the more successful campaign strategies. The final section focuses on participant testimonies to examine what can be learned from these union experiences in the hopes of contributing, insofar as possible, to the discussion on union renewal.
\end{abstract}

\section{KEYWORDS}

Collective action; gendered division of labour; labour transformation; Quebec; union renewal; Walmart; women.

The job market in the province of Quebec, as elsewhere in the western world, has undergone fundamental changes over the last thirty years. Two complementary phenomena stand out: a decline in permanent, stable, full-time employment and an increase in the number of non-standard workers. ${ }^{2}$ The 'new productive model' has introduced a centrifugal movement of jobs towards peripheral markets (Durand, 2004) and a proliferation of employment statuses has led to increasing numbers of jobs that are poorly paid, offer only partial eligibility for private benefits, and provide limited access to public benefits, union representation, and collective negotiation (Noiseux, 2008). Furthermore, these upheavals in the job market have a greater impact on specific categories of individuals according to class, ethnicity, age, and sex (Crespo, 2009). These transformations are neither random nor the effect of 'laissez-faire' policies. Rather, they are the result of decisions made by States and companies consistently guided by the principle of competition (Dardot and Laval, 2009), and these decisions affect not only employment conditions, but living conditions as well. Workers' collective organization and union representation needs, thus transformed, are the focus of this analysis.

Based on a study of the collective struggles of women employed at Walmart and inspired by the approach proposed by Boaventura de Sousa Santos (2004), this article attempts to document worker's workfloor experiences and to mobilize their practices and knowledge in order to contribute 
to the development of a new semantics of organized labour in the adaptation of union activities to new realities. By taking into consideration the interrelated effects of non-standard workers' work and living conditions, we discuss the ways in which organized labour could adapt to the current employment context. This method seeks to counter a kind of fatalism suggesting that, generally speaking, the idea of organizing workers into unions in a post-Fordist context not only lacks legitimacy but is simply not possible among employees forced into peripheral job markets.

With this in mind, it quickly became clear that studying multinational retailer Walmart ${ }^{3}$ was an ideal choice, particularly because some of its Quebec 'associates' had, with the help of the United Food and Commercial Workers (UFCW) union, fought significant union battles during the 2000s. The UFCW campaign in Quebec is particularly interesting because it is unfolding in a North American Wagnerian model of decentralized collective bargaining but situated in a relatively 'labourfriendly' juridical context. ${ }^{4}$ This study has two objectives. First, it illustrates how the dynamics of casualization resulting from the flexibilization of labour have transformed the job market in ways that directly affect workers' work and living conditions. Second, it examines the realities of this service sector, thought by some to be the future of organized labour, by documenting the committed efforts of Quebec unions to reach this category of precarious workers. Two types of data were used: newspapers and academic literature and the results of a study in which women working at Walmarts ${ }^{5}$ in Quebec were interviewed between 2010 and 2012. It is important to note that all study participants were women. ${ }^{6}$ There are two reasons for this. First, women are over-represented in this employment sector. ${ }^{7}$ Second, their lesser-known ${ }^{8}$ reality may provide new perspectives on relevant organized labour theories and practices. We believe that the specific points of view expressed by these employees, several of whom were active unionists, may stimulate new reflections on the future of organized labour. This method follows a bottom-up approach proposed by Sousa Santos, for whom 'the sociology of absences, the sociology of emergences, and the work of translation' (2004: 158) favour empowerment, give voice to these employees, and, most importantly, aim 'to avoid the massive waste of [their] experiences' (2004: 159).

This case study is divided into three parts. In the context of the tertiarization of Quebec's employment market, the effects of the flexibilization of labour at Walmart are first presented through statistical evidence and the comments of the women interviewed. The next section provides an overview of the UFCW's union battles with Walmart in Quebec, including some of the more successful campaign strategies. The final section focuses on participant testimonies to examine what can be learned from these union experiences in the hopes of contributing, insofar as possible, to the discussion on the renewal of trade union practices and strategies.

\section{1. 'Big Box Stores' in the Tertiary Sector and the Flexibilization of Labour at Walmart}

In Quebec, as in many places, tertiarization is the primary engine of economic transformation. Today, almost four of five employees (79.4\%) work in the tertiary sector and one of every eight works in retail (Statistics Canada, 2013a). This means that, in 2011, nearly 300,000 people were employed in Quebec's 24,222 retail industries (Détail Québec, 2012: 44). In the department store sub-sector, Walmart alone generates more than $\$ 4$ billion in sales in Quebec (Détail Québec, 2012: 30).

This labour market transformation is characterized by the casualization of employment conditions and the flexibilization of work. Fifteen per cent of workers employed in retail receive minimum wage (Détail Québec, 2012: 59), for an average weekly salary of $\$ 492$ (CAN) (Détail Québec, 2012: 15). Most retail employees (57.8\%) and 71.6\% of workers in department stores are women (Détail Québec, 2012: 42). Furthermore, women hold two thirds of part-time positions 
(Statistics Canada, 2013a). The retail sector also has limited union representation. Only 18.8\% of employees belong to a union, in comparison to an average of $32.1 \%$ across all of Quebec's industries (Détail Québec, 2012: 61).?

Walmart is particularly interesting not only because it is the world's largest private employer in the tertiary sector, but also as a key actor whose labour management practices grounded in the flexibilization of work exert influence on the entire industry (Biassette and Baudu, 2008; Brunn, 2006; Lichtenstein, 2006; Popu, 2010; Rosen, 2014). In 2014, the number of Walmart employees in Quebec was estimated at 13,000 in its 54 stores through the province, which ranks the company as the tenth biggest private employer in the province. ${ }^{10}$ Specifically, flexibilization is the dismantling of 'rigid' structures within the job market. Boucher and Noiseux define 'flexibility' as a form of liberalization, as applied to work, labour relations, and employment status, that seeks to reduce labour costs to an absolute minimum (2010: 102). The study discussed here confirms with others (Rosen, 2005; Yates, 2011; etc.), that the requirements of flexibilization affect both the work and living conditions of women employed at Walmart. ${ }^{11}$

In terms of work conditions, flexibilization means maximum reduction of personnel-related costs. By necessity, this means offering the lowest remuneration possible. A report on Walmart salaries in the province of Quebec reveals that the starting hourly wage for an 'associate' is $\$ 10.05$ $(\mathrm{CAN})^{12}$ (Meunier, 2013), while the overall average hourly salary is $\$ 10.11$ (CAN), according to the UFCW (Messier, 2013). The pay scale used to determine hourly wages is neither consistent nor public, and employees are required to keep the wage offered upon hiring confidential in order to avoid conflict, a fact to which participants attest. These women also state that their employer's pay scale does not take work experience, responsibilities or seniority into account. Brigitte, for example, was a department manager and cash supervisor with 21 years of experience and a reported hourly salary of $\$ 13.45$ (CAN). Louise is an assistant store manager (the highest position next to store manager) with 12 years of seniority who earns $\$ 14.75$ (CAN) an hour. Staff turnover is so high that employees with this much seniority (and higher salaries) are the exception. ${ }^{13} \mathrm{New}$ employees hired as clerks or cashiers within the last two years (2010-2011, according to the study) make barely more than Quebec's minimum wage.

Limiting labour costs is also achieved through the flexibilization of employment status. The company considers 28 guaranteed hours per week a full-time position, while part-time positions very often consist of 12 guaranteed hours a week or less. However, participants reported being told when they were hired that full-time positions no longer existed at Walmart. And yet, the company requires employees to be available for far more than 12 hours. Women working part-time work an average of 33 hours a week and must be available seven days and two evenings during this same period. As Louise (one of the women interviewed) points out, the company takes advantage of its workers' ambiguous employment status: 'They'll give you your 28 to 30 hours, but you're still part-time. But [the workers] are happy because they're getting hours, but they don't get any benefits. ${ }^{14}$ Furthermore, Walmart gives hours only to those immediately available and applies the same availability requirements to all employees; seniority is not recognized. With the exception of the few employees fortunate enough to have fixed schedules, the same availability requirements (seven days a week/two nights minimum) apply to full-time workers as well. As Bélinda says, 'if you're not available when they want, it gives them a reason to remove your full-time status.' Under these circumstances, employees are unwilling to risk refusing the hours offered, even when it means getting called to come in the same day. Ariel confirms this: 'if you say no, again, it can turn them against you.' It goes without saying that such arbitrary scheduling practices create conflict and encourage competition among workers as they try to become or remain the supervisors' 'favourite' in the hopes of getting more hours. Not only does this system encourage favouritism, it also produces irregular, last-minute schedules that make planning a personal life all but impossible. 
The flexibilization of employment conditions also produces the brutal staffing practice of periodically reducing the number of employees to the minimum required by store traffic. According to Boucher and Noiseux, this allows the employer to '[play] around with workplace norms by hiring only the bare minimum number of employees at any given moment' (2010: 102, original translation). This type of personnel management has significant consequences for employees' daily schedules. For example, although Louise works at a store that opens at 8 a.m., limited customer traffic before 10 a.m. means that, according to her, 'there are hardly any employees on the floor [...]. The schedules are from 10 to 6 or 10 to 7.' This reflects the optimization of labour based on maximizing profit. Fewer employees does not mean less work, however, and the employees who are there have to work twice as hard to keep up during periods when personnel is reduced. Too much work and not enough workers are direct consequences of this management strategy. Yet, the pool of part-time workers is large enough that the employer manages to fill short and split shifts. At the beginning of her career, Bélinda says, it upset her that personnel and work materials were always at a minimum, but she admits that 'you stop fighting and give up.' This is evidence of the normalization of overwork from which the employer profits while often pushing employees to the edge of exhaustion.

Shifting work conditions and the continually changing responsibilities that it implies require that employees be extremely versatile. Personnel are constantly moved to temporarily fill vacant positions. At Walmart, these changes are announced over store loudspeakers. Jocelyne observes: 'You can't say no. [...] If you do, you get a verbal warning that can lead to coaching and, after three times, they let you go.' Participants easily see through the employers' game. According to Horia, 'instead of calling someone in [to fill the empty position] and give them hours, Walmart saves by pulling workers from other departments.' Although changing responsibilities during a shift may seem advantageous if new tasks are less onerous than previous ones, employees must nonetheless catch up on the work left behind as soon as they return to their original post. According to participants, not only do performance requirements remain unchanged but there are surveillance mechanisms in place, such as the number of boxes of merchandise processed at receiving or the number of articles checked out every hour at the cash, to make sure that efficiency does not suffer. Meeting these versatility requirements forces employees to accumulate tasks and responsibilities. Although Rose is a clerk, she finds herself managing different departments: 'What it comes down to is that I do toys, sports, hardware, and sometimes I do seasonal, cash. [...] Last time I was covering five departments at once because there was no one else. It's too much to manage. It's too much to ask.' Employees are both overworked and forced to test the limits of their physical and psychological abilities under the weight of these numerous tasks and responsibilities.

The flexibilization of work conditions has a significant impact on workers' personal lives, an aspect undoubtedly made even more salient in this study by the fact that all interviewees were women. Participants identified three major consequences. First, there is no question that the most immediate and invasive consequence of the flexibilization of work is having a variable weekly schedule. Irregular and unpredictable schedules make it difficult to plan for personal and family obligations, to say nothing of possible leisure activities. Bélinda says that her changing schedule meant that 'I could not commit to anything [...] or participate in activities, take courses.' Aline, head of her household, asserts that she rarely had two days off in a row, which means that 'you don't have time to recover' nor 'have quality time with the children.' By paying particular attention to the gendered division of labour and women's unequal responsibilities relating to childcare and the domestic sphere, ${ }^{15}$ it would seem that irregular work schedules have a major impact on the ability to plan childcare for children too young to stay home alone. Aline concludes: 'You work to pay your babysitter. How you can live on what's left, I wonder.' Not only do availability requirements and unpredictable work schedules intrude on workers' personal lives, they practically control them. 
Financial insecurity is also closely linked to unpredictability in hours worked. ${ }^{16}$ The resulting 'economic stress,' as Rita calls it, is constant: 'you're always calculating.' Furthermore, irregular schedules make budgeting difficult, says Aline. When Walmart workers are the principal source of household income, as is the case for eight of the eleven women interviewed, slower periods and fewer hours are a constant concern. According to the information given by participants, it is possible to estimate their gross income (for a minimum of 28 hours per week) at $\$ 350$ (CAN). ${ }^{17}$ 'There are workers who feed their families on that; when they fall to 28 hours a week [for full-time employees] paid every two weeks, that's not a lot of income,' says Hélène, herself a single parent. Deep cuts to paid hours push employees to work several jobs, visit food banks to avoid bankruptcy, and most of all, be imaginative to make it to the end of the month. ${ }^{18}$

The effort required for employees to make ends meet and remain as available as possible often carries a physical and psychological price. As Rita comments, 'My life continues after work. Often you get home and you can't do anything, you're so tired.' Furthermore, interviewees note a profound fatigue linked to wage labour and the store's overall atmosphere that, for some, has led to the need for medication. Due to supervisors' unreasonable expectations, some of which approached psychological harassment, four of the eleven women interviewed sought relief by asking their doctors for medication. Ariel recounts that she was 'the third woman from Walmart that this doctor had placed on leave because they were too stressed' at work. Workplace threats, intimidation, and abusive surveillance affect employee health. Bélinda tells of a particular situation in which 'a client spit in an employee's face and the company didn't defend her; they defended the client. [...]. There's a total lack of respect.' The effects of such an environment reach beyond the store; they penetrate and shape workers' personal lives.

In general, participants are convinced that the company oversteps its bounds and that their own power is practically non-existent. As demonstrated by their testimonials, labour market transformations affect not only work conditions but personal lives as well; such consequences must be considered together when reflecting on collective action. Participants evoke the injustices they suffer while, in ten out of eleven cases, claim to enjoy their work. In addition to assuring their financial 'survival,' it is a place of accomplishment and social interaction. The employer's success, however, depends on precarious work and living conditions, competition among workers to maintain individualism, and the absence of collective action.

\section{Union Struggles at Walmart: Chronology and Innovations}

A recurrent theme in the vast literature on revitalizing organized labour is the need to focus greater organizational efforts on groups' not traditionally unionized, especially non-standard workers. In this vein, Marie-Josée Dupuis (2004) and Larry Haiven (2003) emphasize the importance of investing in the 'non-union zone,' while Pradeep Kumar and Chris Schenk, in 'Key Renewal Strategies,' prioritize 'organizing the unorganized' on the job market (2004: 4). Charlotte Yates (2004 and 2006), for her part, calls for investment in sectors where certain categories of more precarious workers, specifically youth, women, and migrants, can be reached in order to develop strategies that better meet their needs. Ultimately, as suggested by Edmund Heery and Lee Adler (2004), unionization must be expanded to include those 'at the rough end of the labour market.' This was the goal guiding the UFCW's union struggles at North American Walmarts beginning in the 1990s. From the start, these battles were noteworthy for the employer's anti-union stance, as illustrated by the closure of all Walmart butchery departments in the United States when its butchers in Jacksonville obtained union certification (Adams, 2005: 2). In Quebec, it wasn't until the beginning of the 2000s that the UFCW launched attempts to unionize at Walmart. ${ }^{19}$ An examination of these battles reveals, on the one hand, the lengths to which the UFCW and union 
activists were willing to go and, on the other, the variety of innovations in labour organization resulting from these struggles.

Attempts to unionize Quebec Walmarts began in December 2003 when the UFCW submitted its first certification request to Quebec's labour relations board, the Commission des relations du travail (CRT) so that it could represent workers at the Jonquière store. The company challenged the request, claiming that the certification unit failed to meet all the necessary criteria by excluding department managers. In March of 2004, the CRT upheld the exclusion of department managers from the certification unit and ordered a vote that was subsequently lost by a narrow margin (Adams, 2006: 4). The union then submitted a new request in July 2004. Although Walmart again challenged on the same grounds, the CRT approved the request and the Jonquière store became the first to be unionized in North America. Walmart was now obligated to engage in negotiations but the parties could not agree and the union requested arbitration to establish the terms of a collective agreement. In February 2005, the very day of arbitration, Walmart announced that the store would be closed for failing to meet its sales targets. Employees and the union submitted several requests for redress and the legal battle has continued into $2014 .{ }^{20}$ The Jonquière store's closing nonetheless succeeded in slowing attempts to unionize other Walmart stores during the same period ${ }^{21}$ and, above all, showed that the employer's threats of closure could actually be carried out. In October 2004, the UFCW filed a request for certification on behalf of the SaintHyacinthe store. The CRT approved the request in January 2005. Once again, Walmart challenged the certification unit's viability and it was not until April 2006 that the Supreme Court of Canada rejected the appeal and confirmed the certification. ${ }^{22}$ According to Roy J. Adams, the fact that the Saint-Hyacinthe store was one of the most profitable in Quebec made it difficult for the company to threaten closure for economic reasons (2005: 6). Negotiations stagnated, making arbitration necessary to ratify the employment contract in April 2009. In the meantime, staff turnover was weakening the unit: 'nine months after the union was certified, $65 \%$ of store workers in the region had left the company' (The Canadian Press, 2011, original translation). Thus, the collective agreement, retroactive to the date of certification, was only in effect for a few months; the renewal period ended with the union's revocation in March 2011 due to lack of support. A third union had obtained certification in Quebec in 2005, and in 2008 Walmart's first collective agreement, specifically with employees of the Gatineau store's automotive department, was ratified through arbitration. The agreement granted workers a significant wage increase: initial hourly wages of $\$ 9.25$ were to reach $\$ 15.94$ in 2010 (Parent, 2008). During negotiations, Walmart claimed that 'the future of the tire center depends on the contents of the collective agreement' (Parent, 2008, original translation). However, the CRT revoked the union's certification in March 2010. Louis Bolduc of the UFCW explains that revocation resulted from the employer's pursuit of numerous legal avenues: 'Walmart bogged us down in technicalities, during which time employees left, new ones came who didn't support us, and soon the union no longer represented a majority of employees' (The Canadian Press, 2010, original translation). The UFCW submitted its first certification request for a second store in Gatineau, this time in the Hull sector, in May of 2005. Due to some uncertainty concerning the number of signatures, the UFCW ordered a secret vote. A second request with sufficient signatures was submitted a few days later. The CRT certified the union in December 2008 despite, again, Walmart's objections (Dufault, 2008). Employment contract negotiations begun at this time ended in August 2010 when a collective agreement retroactive to the date of certification was imposed (Duquette, 2010). But, once again, the union was disbanded soon thereafter, in November 2011. The employment contract had only been in effect for a little over a year. Despite these setbacks, the movement remains active in Quebec. Inspired by the OUR Walmart movement in the United States, ${ }^{23}$ the NOTRE Walmart campaign was launched in the fall of $2013 .{ }^{24}$ This represents a new strategy for the UFCW: 'We prefer to help employees come together. To do this, we will train 
them, coach them, and support them. The day they decide to unionize, it will be their decision' (Laprade, 2013, original translation). This non-institutional alternative allows 'associates' to break out of their isolation and individualism in favour of working together to demand that Walmart provide respect and dignity in the workplace.

To continue the fight for organized labour, in addition to long legal battles, the UFCW has been forced to develop new strategies that take the employment sector's precariousness and the employer's anti-union stance into account. The UFCW has had to move beyond the philosophies and habits of business unionism and the tactics traditionally associated with the 'servicing model,' a form of organized labour that perceives workers primarily as wage-earners most interested in shortterm economic gain (Kumar and Schenk, 2006: 82-83). Certain aspects of the Walmart union campaigns suggest strategies inspired by an 'organizing model' that aspires to give more power to union members and increase focus on education and raising awareness (Kumar and Schenk, 2006: 82-83). Three elements will be examined: the organization's efforts to fight against the casualization of the workplace, its desire to adapt to the needs and realities of tertiary sector workers, and innovations made in union practices.

First, since the 2000s, one of the UFCW's primary motivations for unionizing Walmarts has been to fight the increasing labour flexibilization and casualization of part-time work (Adams, 2005; Gondziola, 2005), the multiple consequences of which are clearly seen in participant comments. The UFCW encouraged workers to unionize so that, collectively, they could improve employment conditions by changing the balance of power between them and their employer. This has proven very difficult. By trying to unionize Walmart workers, the UFCW hoped to 'improve the retail giant's working conditions rather than watch its competitors do the opposite' (Castonguay, 2004, original translation), particularly because the province of Quebec was expecting the arrival of similar companies (specifically, Target in 2013). Although the UFCW's principal motivation was to improve Walmart employees' economic situation, its larger vision included a critique of the ways in which the world of work was being transformed. By investing in less-unionized peripheral markets, it hoped to counter the increasing casualization of employees' work and living conditions.

Second, these campaigns demonstrate labour organizations' willingness to adapt to the needs and realities of precarious workers in non-standard employment. Indeed, the traditional 'bread and butterism' based on wage increases and short-term economic gain so effective in business unionism would not be enough (Kumar and Murray, 2006: 82). Demands had to encompass broader economic and social changes that would affect Walmart workers' work and living conditions. For example, issues related to 'variable schedules' and 'part-time employment status' were central to demands formulated by UFCW section 503 in Jonquière (L'internationaliste, 2005, original translation). ${ }^{25}$ Although all of the collective agreements were imposed through arbitration, each contained minimal, but indispensable, improvements in work conditions: small wage increases (to cover union dues), the introduction of grievance procedures, and the establishment and recognition of seniority. ${ }^{26}$

Third, these union struggles stimulated innovation in campaign strategies in order to circumvent the employer's anti-union strategies and reach isolated workers in different departments. Importantly, from the beginning, the UFCW supported the campaign activities of groups whose members were mostly women. In Jonquière, organizers first launched the campaign, without success, in a male-dominated department. It gained ground, however, when two women joined: "The difference was that they were cashiers, which is a big department in the store, and much more popular with their co-workers. [...] They also had very strong personalities and were not afraid of the store managers' (Bianco, 2006). Given that most of the personnel were women, the UFCW recognized that they would play a key role in these campaigns. Organizer training and the involvement of many union officials were made possible by the Special Project Union Representatives 
Program, originally established in 1990. This program is based on the belief that non-organized workers will respond more readily to leaders whose profiles are similar to their own (Adams, 2005: 6). ${ }^{27}$

Another of the UFCW's innovations was a strategy based on direct personal contact with potential union members rather than collective or mass communications, such as flyers or public meetings, which were thwarted by the employer's anti-union tactics. ${ }^{28}$ Instead, personal information sessions were conducted outside of working hours (Adams, 2005: 7). According to a study by Yates (2006: 109-110), this one-on-one strategy appears to be more successful with women than with men. During periods of recruitment or certification, all communication had to take place outside of the stores to avoid the watchful eyes of anti-union superiors and colleagues.

Battles waged by Walmart employees led the UFCW to adopt new strategies for rallying public opinion, which meant developing a message critical of the employment market and closer to the idea of organized labour as a social movement. Relationships were established between union organizations and other 'civil society' group. ${ }^{29}$ The UFCW joined the National Union of Public and General Employees (NUPGE) to defend the idea that worker rights are human rights and participated in a campaign criticizing the Canadian government for claiming to support fundamental rights set out by the International Labour Organization without actually incorporating them into its legislation (Adams, 2005: 8). Along with the NUPGE, the UFCW also helped fund a film to raise awareness about the effects of Walmart's antisocial behavior (Adams, 2005: 9). The organization also sought to educate and raise awareness through different methods, including electronic media, ${ }^{30}$ in the hopes that creating a connection between consumer and citizen would increase the public's sense of collective responsibility. Indeed, workers interviewed for this study reported receiving support from customers who claimed to shop only at unionized Walmarts. In 2012, in the interest of social unionism, the UFCW participated in UNI Global Alliance Walmart, ${ }^{31}$ an international network fighting for Walmart workers' rights to equity, justice, decent work conditions, and organized labour.

Although the revocation of Walmart unions is disappointing given the dedicated efforts of activists and the UFCW, the fight continues: '[the employees] will keep trying until they're unionized!' affirms Ginette. That said, such enthusiasm is no substitute for the organized labour movement's careful consideration of what can be learned from these experiences.

\section{What Can Be Learned From Unionization Experiences?}

If the future of organized labour in Quebec lies in the labour market's growing, primarily female $(57.8 \%)$, and under-unionized $(18.8 \%)$ tertiary sector, there are important lessons to be learned from the Walmart union experiences of women interviewed for this study. Based on their comments, the following three elements must be examined: who is being unionized, what a union campaign should look like, and what these specific potential union members need.

\section{Who is being unionized?}

This first question does not imply the essentialization of those involved in the unionization process, that is, it does not assume that certain personality traits are naturally associated with all women rather than men, for example. As a starting point, however, it does invite analysis of the material conditions and structural constraints whose impact is greater on certain categories of individuals and, therefore, on their relationship to work and organized labour. As Yates states, 'The first thing that unions need to do is recognize that they are not just organizing workers; they are organizing women whose work experience and structural position in the labour market are different from those of men' (Yates, 2006: 110). In other words, the strategies so successful in union 
campaigns and representation in male-dominated milieus are not easily transferable to employment sectors in which women are the majority. Moreover, a study of the UFCW conducted by Joëlle Cuillerier shows that 'leadership and organizational structures remained unchanged when applied to the specific needs of Walmart employees,' meaning that these campaigns conducted in Quebec were managed like any other (2010: 107, original translation). ${ }^{32}$ Asking who is being unionized makes two preliminary assumptions. On one hand, in terms of job market realities and as Horia observes, it seems that what she calls 'factory men' are easier to mobilize and convince of the need to unionize because work conditions and responsibilities in factories and on worksites produce very similar experiences. However, in a world of 'women in department stores' in places like Walmart, responsibilities are much more compartmentalized and associated with different levels of privilege and status. The increasing complexity of employment conditions makes it more difficult for labour organizations to use the same strategies to defend the interests of all employees in similar positions, as they had previously done (Noiseux, 2008: 374). Furthermore, the idea that workers identify as a single group - something most employees do not necessarily agree with - must be reconsidered in light of the variety of ways in which they relate to their work, and this means questioning, according to Yates, '[the] dominant understanding of work and workers' relationship to employers and labour markets [that] are framed in universalistic, non-gendered terms' (2011: 589). Indeed, an examination of the gender segregation of Walmart's workplace ${ }^{33}$ reveals that women's work conditions are more severely affected by flexibilization, which inevitably leads to even greater precariousness in living conditions.

On the other hand, in terms of social realities, it would seem that, for a significant proportion of the labour force (with the exception of students), Walmart is the employer of last resort when other options seem unlikely and such limited income becomes an economic necessity. For these reasons, the possibility of losing one's job due to store closure is a terrible threat. For Horia and Hélène, there is no doubt that the 'personnel's vulnerability' results from public and private constraints that labour organizations cannot afford to ignore. Bélinda adds to this by affirming that her colleagues 'experience too much misery, are too overwhelmed by their own problems' to think about collective action. As demonstrated in research by Yates (2006: 100), it appears more difficult to convince women to join a union than men because '[they tend] to take longer to make a decision to join a union,' which increases their exposure to their employer's very effective anti-union disinformation strategies. However, once they have joined, 'they were less likely than men to change their mind' during the process (Yates, 2006: 110). Stopping to examine who is being unionized, that is, not assuming from the outset that all employees share the same reality (taking into consideration sex, class, or race), makes it possible to identify material conditions and structural constraints that influence a person's disposition and receptivity to unionization or joining the fight. For women who want to participate in union campaigns, availability outside of paid working hours remained a significant obstacle (as domestic and family responsibilities fall unequally to them). Participants were even more concerned about the potential consequences of union involvement. Hélène, for example, was worried that she might be forced to find another job if attempts to unionize were unsuccessful or if the company decided to wrongfully dismiss her: 'I'm a single parent, if something happens, I'll be banned throughout the region.' In order to understand who is being unionized, labour organizations must develop a reading sensitive to gendered realities (i.e. differentiated worklife balance issues, scheduling needs, gender segregated workplaces, access to promotions and responsibilities, etc.) and therefore consider the interconnected effects of the patriarchal and capitalist systems. Undeniably, not all campaigns can be run the same way. 


\section{What should a union campaign look like?}

Asking this second question does not invite the establishment of an ideal series of steps to creating a successful union campaign, but rather suggests a starting point. According to participants, the first and most significant obstacle to organized labour is ignorance of workers' rights. Rose believes that the principal impediments to mobilizing employees are 'shame, fear, and lack of information.' Due to insufficient information and the ignorance of rights and existing recourse procedures, workers are vulnerable in relation to their employer: '[employees] don't know that they have rights,' laments Hélène. From this perspective, the UFCW's OUR Walmart campaign to mobilize workers through political education is entirely justified. That said, rights education should not become, in practical terms, the sole responsibility of labour organizations. An interesting alternative is the creation of sustainable coalitions among different community and political actors, one of the strategies associated with the revival of organized labour proposed by Kumar and Schenk (2006: 86). According to a study conducted by Cuillerier (2010: 124-125), a limited number of strategies of this type belonging to the organized labour movement's repertoire were used by the UFCW during its Walmart union campaigns. Her analysis shows that no sustainable alliances were created in any of the communities in which these campaigns took place (Cuillerier, 2010: 149). This approach focuses on the importance of bringing citizens, communities, and unions together in order to create education campaigns about individual and collective rights.

Turning to what campaigns should look like, the women interviewed emphasized the importance of sending positive messages about organized labour that highlight its relevance to this employment sector (recognizing seniority, posting job openings, grievance procedures, etc.). According to Bélinda, negative messages, such as 'unions don't do anything, all you do is pay dues,' abound. It would seem that explanations for why union dues are needed to pay for various member services are required before campaigns even begin. On the one hand, union dues can seem exorbitant compared to workers' limited salaries. Louise notes that employees in her store wondered why they should unionize, given their weekly wages: 'you're going to give money to the union knowing full well that you won't get anything in return, Walmart will never negotiate.' On the other hand, from an individual point of view, paying union dues can seem like a waste of money in a context where Walmart unions have had very limited success thus far (primarily due to the employer's anti-union tactics). This perception is exacerbated by the fact that members evaluate unions according to their ability to 'settle' grievances, a process Walmart was making very difficult. Nonetheless, it appears that placing 'union services' in a positive light is necessary to counter the anti-union message that circulates from store to store: 'Everything we hear about the union is bad [...] Walmart is spreading disinformation, always,' concludes Aline.

Participants also speak of difficulties related to information distribution methods and communication with the labour organization. First, communication among store delegates and union officers became problematic. However, problems '[...] related to the application of internal structures and leadership, including limited member involvement in the union's daily activities, difficulty mobilizing, vertical decision making, and inequalities linked to sex and race [...]' appear to go unmentioned by the UFCW's union officials consulted in Cuillerier's study (2010: 108, original translation). UFCW's officials were present in stores when the campaigns were launched and it was their support that convinced many to join the fight. Despite this, once certification was obtained, delegates experienced intimidation from both employer and anti-union colleagues in isolation. Long periods of uncertainty caused by Walmart's legal action and contract negotiations gave the impression that the union was 'inactive', absent, and 'powerless' before the employer. The same was also true after employment contracts had been imposed. As Jocelyne says, 'Honestly? We never saw them. [The union reps] came by once a week. But that's as far as it went.' Another participant, Ginette, recalls that the goal of the union official's visit was to confirm that scheduling 'respected 
seniority.' Furthermore, the methods the union used to communicate with members were inadequate. Each store had only one bulletin board reserved for union use (which everyone avoided for fear of being seen), in addition to a website managed by the UFCW. Hélène, however, insists that 'we have nothing other than the bulletin board,' no complete list of employees, no list of telephone numbers or email addresses. For her, despite modern technologies, it seemed impossible to distribute information or communicate what was being done. Moreover, methods like general assemblies and public information sessions traditionally favoured by unions (whether during recruitment or while the employment contract is in place) were ineffective. Horia states that employees were afraid of attending general assemblies or information sessions because they were compromised: 'There were even two people who attended [the assembly] who had agreements with management to see what was happening, see what the union was saying.' As stated by Kumar and Schenk (2009: 89-90), the union's internal activities must be efficiently communicated at every step of the process, and this requires innovation, particularly in the use of new communication technologies.

\section{What do these specific potential union members need?}

This third question requires examining the specific needs of the individuals being unionized. Potential union members' interests are influenced not only by employment sector but also by each sector's particular constraints. With this in mind, Yates invites labour organizations to look more closely at gendered workplace inequalities, the material and structural conditions that determine accessibility to and availability for employment, and, ultimately, the effects of sex segregation at work on employment market organization (2006: 110-111). While it is true that union struggles have resulted in important gains specifically for women, such as pay equity, maternity leave, and workfamily balance policies, most of the Canadian women who benefit from these advances work in the public sector or have full-time employment. This leaves women who work part-time for minimum wage in far more precarious positions (Yates, 2011: 586). As mentioned above, the desire to fight these kinds of work conditions led to the UFCW's attempts to unionize Walmarts. Participants in this study identified five objectives they felt required union representation: fair and public pay scales, choice of schedules, recognition of seniority, freedom to express their opinions, and access to grievance procedures.

The first objective, fair and public pay scales, is of particular interest for these women because they may counteract the employer's favouritism and the competition and divisions it creates among them. Despite meagre salaries, economic considerations are not the priority. Brigitte states: 'As far as salary goes, it's funny, but that's the least of my worries. I would rather get the same pay but be happy to go to work because things are fair.' Horia agrees and adds that the biggest issue is irregular work schedules (and their impact on earnings), especially for women. Asking who is being unionized (women) and what they need reveals the extent to which the public (work) and private (family and community) spheres overlap in daily life. Thinking, along with the workers themselves, about improving work conditions means considering the permeability of these spaces (that cannot be analyzed separately) and facilitating their articulation through different policies. ${ }^{34}$ The second objective, choice of schedules, was one of the union's official grievances, although the specific needs identified disappeared during negotiations. Indeed, certain things were 'forgotten' in the final collective agreements, all of which were negotiated in contexts marked by the threat of closure or reduced salaries. Horia recalls that a 'forgotten' word could have serious repercussions for work and living conditions. Such negotiations represent opportunities to expand the conception of workers often understood only in relation to their wages and situate them instead as citizens who want a better work-life balance. According to Horia, the phrase 'preferred shifts' had been decided upon for the paragraph discussing availability. The adjective 'preferred' would have allowed workers to 
indicate realistic availabilities aligned with their personal lives. However, "they put 'shifts' instead of 'preferred shifts'. [...] We had said it, but the guy who negotiated 'forgot'," she laments. This 'forgotten' element could have greatly improved the workers' ability to manage work-life balance. Alliances among labour organizations, the women's movement, and feminist labour activists could be particularly beneficial, given their respective areas of expertise relevant to these issues.

The women interviewed see the last three objectives, recognition of seniority, freedom to express their opinions, and access to grievance procedures, in terms of justice at work. They echo what Yates calls “'new age' organizing issues of dignity, fairness, and voice." (2006: 109) They seek these things because they are physically and psychologically exhausted by their employer's excessive demands. Ultimately, in order for union members' needs to be heard, the union's internal democracy must remain a central concern while increasing member involvement in union structures, as proposed by the 'organizing model'.

In sum, labour organizations must consider each of these objectives as they aim to renew labour practices in light of the realities and needs of potential union members. However, the employer's anti-union stance considerably complicates things. Furthermore, other issues, such as the legal system, the right to work, and governmental and economic policies influencing union struggles, must also be discussed. It nonetheless remains that the study participants involved in these battles are convinced of the need for organized labour. Collective organization would seem the most promising method to fight against the increasing precariousness of work and living conditions as well as Walmart's excessive use of power.

\section{Conclusion}

To conclude, this analysis shows how the arrival of Walmart in Quebec, the 'flagship company' of twenty-first century capitalism, participates in the dynamic of neoliberal market globalization driven by the flexibilization of work and its corollary, precariousness. Reliance on poorly-paid labour allows this business model to play favourites and ease particular employees' work and living conditions on a case-by-case basis. The system reinforces individualism and mutual competition and thereby maintains the employer's position of power. Walmart union campaigns led by the UFCW reveal the difficulties faced by labour organizations who, in trying to reach nonstandard workers in particular market sectors (specifically the service sector), must confront companies known for their anti-union stance. Testimonials of women who work in Quebec Walmart stores illustrate the consequences of the heightened demands of flexibilization and their effect on both work and living conditions. These employment realities and consequences on workers' private lives is a seemingly inescapable vicious circle that mutually reinforces the demands of flexibilization and various types of precariousness. Given the strength of the neoliberal capitalist system and its multinational players, such as Walmart, places of individual and collective resistance may be few, but they do exist.

Even if this study focuses especially on Quebec's reality and the results cannot be generalized to all contexts, we should consider the importance of resisting fatalism by learning from those specific experiences. Furthermore, we do think that the issues encountered by women working in Quebec's Walmarts have a lot in common with women working in Walmart throughout the world. Close consideration of the UFCW's Walmart union campaigns demonstrate that collective organization is still possible and that there are workers, even in the precarious tertiary sector, willing to take up leadership roles in the movement. One lesson is clear, however: labour organizations must develop a reading sensitive to gendered realities by considering the interaction of public and private spheres and their respective constraints in order to facilitate an understanding of these workers' specific organizational and union representation needs. Taking this into consideration, it would be 
interesting to cross-examine further union organizers on how (and when) they will adopt new tactics and strategies in regards to those gendered realities (or why they haven't been able to fully address this matter in the current case).

Finally, it should be stated that without losing hope that collective action is the most promising strategy against Walmart, the women who participated in this study expect a minimum of effort from the government. According to them, government authorities must ensure that current laws are respected by every company operating in Quebec. Given the results of this study, if changes to Quebec's labour standards were to be proposed, being advised of your work schedule at least one week in advance and equal treatment regardless of employment status are suggested as starting points to improve the work and living conditions of workers who find themselves in peripheral employment markets.

\section{NOTES}

1. Translated from French by Catriona LeBlanc.

2. Non-standard work in peripheral employment markets, as defined here, includes part-time, temporary, self-, and cumulative employment, as well as invisible work (illegal work, work by 'illegal' immigrants and caregivers, and work legally performed by seasonal migrant workers, etc.). For a discussion of the definition of non-standard work, see Noiseux (2008: 21-25).

3. In order to establish itself in Quebec in 1994, Walmart bought non-unionized Woolco stores.

4. For example, unionization in Quebec can be certified without secret ballot voting if the Labour Board confirms that a majority of employees have signed a union card.

5. This study examined the effects of market liberalization on women's work and living conditions. See: Mayer, S. (2013) Les effets de la libéralisation des marchés sur les conditions de travail et de vie des femmes. Le cas Walmart. Montréal: Les Éditions IEIM. The authors would like to thank F. Descarries, D. Brunelle, L. Kurtzman and G. Bourret, members of the team that guided this research, for permission to use these data for this article.

6. Eleven women from six different Walmarts in Quebec were interviewed and received \$50 (CAN) in compensation. In conformity with this study's research protocol, anonymity and confidentiality were assured to all participants. Participants' places of work are not revealed and fictional names are used in order to protect them from Walmarts retaliation practices. When referring to their interviews, we will use their fictional names: Rita; Rose; Brigitte; Bélinda; Hélène; Horia; Jocelyne; Ginette; Louise; Aline and Ariel. The semi-structured interviews lasted an hour and half on average. The workers were selected based to assure diversity in age, marital status, places of work and employment status. Thus, the participant's age varied between 18 and 60 . Out of eleven, eight participants earned the only family income; seven were full-time; six were directly involved with in the union drive and, worked for an average of ten years for Walmart. A non-probabilistic sampling method was used. The invitation to participate in this research circulated in three networks: the regional feminist centers in Quebec ( $L$ 'R des Centres de femmes), UFCW members (women involved in the unionization) and on social network (Facebook, for example). Recruitment directly in stores was a failure, women were frightened by our presence (participation to any research is forbidden by the employer). A relationship of trust was the key for their willingness to participate and more elderly workers with full-time positions were more enthusiastic about the study. 
7. Women constitute the majority (58\%) of workers in the retail sector (Détail Québec, 2012: 15). In the department-store subsector in which Walmart operates, the female workforce is particularly predominant, reaching 71.8 percent (Détail Québec, 2012: 15). Around 70\% of Walmart store employees in United States are women (Rosen, 2005; Jeanneau, 2007). Walmart does not disclose the female to male ratio of their workforce in Quebec.

8. In general, studies on work conditions and organized labour at Walmart are based on secondary data (see, for example: Adams, 2005; Cuillerier, 2010; Lichtenstein, 2006; Noiseux, 2008). However, a Human Rights Watch report (2007) is based on interviews with Walmart employees, as is a study by Featherstone (2004) recounting the experiences of women involved in Dukes v. Walmart Stores, a class action lawsuit. Another exception is Rosen (2005) study based on extensive interviews with Walmart workers where she documents Walmart's paternalistic culture and shaming practices but does not directly address worker's collective organization. To our knowledge, no study has given voice to women working at Walmart in Quebec by asking about their work and living conditions and their union experiences.

9. Data from 2010. The retail sector's unionization rate in Quebec has declined slightly since 2001 (20.2\%) (Détail Québec, 2012) and is more or less the same as the one in the larger 'private service sector' (19.8\% in 2013). This being said, it is well higher than the unionization rate in the retail sector in the 'rest of Canada' (12.7\% in 2010).

10. Journal Les Affaires. Data from 2014. While Walmart is not the biggest retail sector employer - the grocery chain METRO has 32,500 employees, - it is, by far, the biggest 'big box store' employer in the province. For example, Costco is a far second with its 5,800 employees.

11. Many studies already revealed the deleterious work conditions in Walmart in United States (such as Brunn, 2006, Lichtenstein, 2006 or Rosen, 2014). This confirmed those practices in Quebec's Walmarts but also reveals the impacts of the company's practices on 'living conditions' of women working at Walmart.

12. In 2013, Quebec's minimum wage was $\$ 9.90$ (CAN) an hour.

13. According to Biassette and Baudu, Walmart's official statistics indicate that 'approximately half of these lucky men [and women] throw in the towel after a year or less' (2008: 119, our translation).

14. All participants quote in this article were originally in French.

15. Statistics show that eight of ten single-parent families are led by women, and that these families' incomes are significantly lower than single-parent families led by men (Statistics Canada, 2013b).

16. The UFCW's website for Walmart employees indicates that the average annual 'associate' salary in Canada (for all employment statuses combined) is $\$ 14,174$. See: www.employesWalMartcanada.com, [Accessed 10 March 2010].

17. Seven out of eleven women were employed full-time. Three of these shared with us their hourly wage: Brigitte, \$13.45; Horia, \$11.45; Louise, $\$ 14.75$.

18. In the United States, it appears that the situation has reached a crisis point. A report by the Democratic staff of the U.S. House Committee on Education and the Workforce states that 'When low wages leave Walmart workers unable to afford the necessities of life, taxpayers pick up the tab' and, in the case of employees in Wisconsin, the bill for state assistance is an estimated $\$ 904,452$ USD (Zeiler, 2013). Because their salaries are insufficient to meet their needs or those of their families, they must turn to government aid, particularly food stamps. One proposed solution is raising minimum wage. See: http://democrats.edworkforce.house.gov/ sites/democrats.edworkforce.house.gov/files/documents/WalMartReport-May2013.pdf. 
19. UFCW has 250,000 members in Canada. Its 45,000 members in Quebec makes it the largest union in the retail sector (CSN's Fédération du commerce has a total number of 8,900 members in the larger 'commerce sector'). With its 11,000 members, UFCW/TUAC Local 501 is the largest of the six UFCW sections in Quebec. Women constitute a majority of UFWC-Canada membership. See UFCW's website: 'Au sujet des TUAC au Québec', Available at http://www.tuacquebec.ca/index.php/notre-syndicat/au-sujet-des-tuac, [Accessed: 19 December 2014]. The Metallos/United Steelworkers are also active in the retail sector in Quebec.

20. In December 2013, the Supreme Court of Canada judges began deliberations. Based on article 59 of Quebec's labour code, which freezes working conditions following the creation of a union, the UFCW claims the employer illegally closed its store in February 2005 (Desjardins, 2013).

21. For example, in April 2005, the Brossard Walmart's union certification vote in Longueuil was unsuccessful (Le Devoir, 2005).

22. The CRT had certified a unit of workers from the store's automotive department in May 2005.

23. Visit the official page at http://forrespect.org/, consulted February 12, 2014.

24. Visit the official page at http://notrewalmart.ca/, consulted February 12, 2014.

25. The women involved in the unionization drive first wanted to get their unit certified in spite of Walmart anti-union battle. The motivations for their unionization attempt are largely discussed in the next section. The strategy was to mainly address the work conditions issues in the first collective agreement. This being said, some demands addressed the schedule issue (for full-time and part-time employees) in order to make it more suitable for family responsibilities and worklife balance. As Horia and Hélène mentioned, more demands aimed at connecting work and family issues were ready for the second collective agreement negotiation, but it never happened.

26. The establishment of policies recognizing seniority in work schedule creation is among the more significant achievements of the collective agreements signed in 2013 by union members employed by Couche-Tard franchise stores in Quebec (ongoing research, see www.practa.ca).

27. It is interesting to note that the women interviewed in this study refer only to male UFCW organizers; female organizers were not mentioned. This echoes a Canadian study (British Columbia and Ontario) conducted by Yates showing that a large majority of organizers are men, which in turn influences where and how unionization happens (2006: 108-109).

28. Louise mentioned a situation where collective tactics were used without success: 'Union reps came into the store in 2010 and walked around passing out their phone number. [...] The manager arrived and asked them to leave the store. After that, they picked up all the cards right out of the employees' hands' (original translation).

29. For a discussion of renewed interest in organized labour, see Esteves 2006, Adams 2005, and Featherstone 2005.

30 The following websites are examples: 'Wake up Wal-Mart' http://www.wakeupwalmart.com/, and 'Wal-Mart Class' http://www.walmartclass.com/public_home.html.

31 For more information on this alliance, see: http://www.tuac.ca/index.php?option=com _content\&view=article\&id=3170:walmart-the-focus-of-global-action-today-involving-canadaand-9-other-countries\&catid=6:directions-newsletter\&Itemid=360\&lang=fr.

32. The only element that distinguishes the UFCW's Walmart campaigns from previous ones is the resources dedicated to them, which far surpassed the average (Cuillerier, 2010: 108). 
33. Women are very often employed as clerks and overrepresented in cashier positions, while men are assigned to receiving or building maintenance. The cashier department, for example, is the one most significantly affected by the requirements of flexibilization such as cut and shortened schedules.

34. This does not imply assuming that the needs of women workers who are single parents or responsible for children apply to all employees. However, as Yates states, 'there is an inseparableness of women's roles and social responsibilities of caring and their limited choices for work, and ways of approaching work' (2011: 598).

\section{REFERENCES}

Adams, R.J. (2005) 'Organizing Wal-Mart: The Canadian Campaign,' Just Labour. 6/7. [Online] Available at http://www.justlabour.yorku.ca/volume67/pdfs/01\%20Adams\%20Press.pdf, [Accessed: 10 April 2014].

Bianco, A. (2006) 'No Union Please, We're Wal-Mart,' Bloomberg Business Week. February 12. [Online] Available at http://www.businessweek.com/stories/2006-02-12/no-union-pleasewere-wal-mart, [Accessed: 10 April 2014].

Biassette, G. and Baudu, L.J. (2008) Travailler plus pour gagner moins. La menace Wal-Mart, Paris: Buchet/Chastel.

Boucher, M-P and Noiseux, Y. (2010) Effets de la libéralisation des marchés sur les conditions de travail des Québécoises: huit études de cas. Brunelle, D. Descarries, F. and Zurtzman, L (eds.). Montreal: Les Cahiers de l'IREF.

Brunn, S.D. (ed.) (2006) Wal-Mart World: The World's Biggest Corporation in the Global Economy. New York: Routledge.

Canadian Press (The) (2010) 'Wal-Mart à Gatineau : les TUAC essuient une défaite,' La Presse. May 21. [Online] Available at http://affaires.lapresse.ca/economie/commerce-de-detail/201005/21/ 01-4282613-wal-mart-a-gatineau-les-tuac-essuient-une-defaite.php, [Accessed: 10 April 2014].

Castonguay, A. (2004) 'Wal-Mart: Jonquière dit non au syndicat,' Le Devoir. April 3. [Online] Available at http://www.ledevoir.com/economie/actualites-economiques/51448/wal-martjonquiere-dit-non-au-syndicat, [Accessed: 10 April 2014].

Crespo, S. (2009) 'Les travailleurs pauvres, témoins et acteurs des mutations sociétales en cours,' Liens sociales et politiques. (61): 123-136.

Cuillerier, J. (2010) Les stratégies d'organisation syndicale dans les multinationales du secteur des services traditionnels: Le cas de Wal-Mart Canada Inc. Master's thesis, Montreal University.

Dardot, P. and Laval, C. (eds.) (2009) 'Discipline (1): un nouveau système de discipline,' in La nouvelle raison du monde. Essai sur la société néolibérale. Paris: La Découverte. 
Desjardins, F. (2013) 'Fermeture du magasin de Jonquière - Wal-Mart et le syndicat devant la Cour suprême'’ Le Devoir. December 7. [Online] Available at http://www.ledevoir.com/economie/ actualites-economiques/394622/wal-mart-et-le-syndicat-devant-la-cour-supreme, [Accessed: 10 April 2014].

Détail Québec (2012) Diagnostic sectoriel de la main-d'ouvre du commerce de détail au Québec 20122015. Montreal: Comité sectoriel de la main-d'œuvre du commerce de détail. [Online] Available at http://www.detailquebec.com/assets/files/Diagnostic_2012_2015_VF.pdf, [Accessed: 10 April 2014].

Détail Québec/Altus Géocom (January 2009) Diagnostic sectoriel de la main-d'ouvre dans le commerce de détail. Montréal: Comité sectoriel de la main-d'œuvre du commerce de détail.

Devoir (Le) (2005) 'Wal-Mart: Brossard dit non au syndicat,' Le Devoir. April 2. [Online] Available at http://www.ledevoir.com/economie/actualites-economiques/78484/wal-mart-brossard-ditnon-au-syndicat, [Accessed : 10 April 2014].

Dufault, F.P. (2008) 'Les négociations peuvent commencer,' La Presse. December 19. [Online] Available at http://www.lapresse.ca/le-droit/actualites/actualites-regionales/200812/19/01812084-les-negociations-peuvent-commencer.php, [Accessed: 10 April 2014].

Dupuis, M-J. (2004) Renouveau syndical: proposition de redéfinition du projet syndical pour une plus grande légitimité des syndicats en tant que représentants de tous les travailleurs. Montreal: CRIMT.

Duquette, P. (2010) 'Le Wal-Mart du Plateau se syndique,' La Presse. October 8. [Online] Available at http://www.lapresse.ca/le-droit/actualites/ville-de-gatineau/201010/07/01-4330608-le-walmart-du-plateau-se-syndique.php, [Accessed: 10 April 2014].

Durand, J-P. (2004) La chaîne invisible, Travailler aujourd'hui: Flux tendu et servitude volontaire. Paris: Editions du Seuil.

Esteves, O. (2006) 'Résistances populaires,' Monde Diplomatique. January 2006. [Online] Available at http://www.monde-diplomatique.fr/2006/01/ESTEVES/13090, [Accessed: 10 April 2014].

Featherstone, L. (2004) Selling Women Short. The Landmark Battle for Workers' rights at Wal-Mart. New York: Basic Books.

Featherstone, L. (2005) 'Wal-Mart's P.R. War,' Salon.com. August. [Online] Available at http://www.salon.com/2005/08/02/walmart_5, [Accessed: 10 April 2014].

Gondziola, J. (2005) 'Wal-Mart's Culture of Control,' Canadian Dimension. [Online] Available at http://canadiandimension.com/articles/1923, [Accessed: 10 April 2014].

Haiven, L. (2003) 'The Union and the Non-Union Zone: A Framework for the Challenge to Unions to Organize,' Just Labour. 3: 63-74. [Online] Available at http://www.justlabour.yorku.ca/ volume3/pdfs/haiven.pdf, [Accessed: 10 April 2014]. 
Heery, E. and Adler, L. (2004) 'Organizing the Unorganized, Varieties of Unionism,' in Kelly, J. and Frege, C.J. (eds.) Strategies for Union Revitalization in a Globalizing Economy. Oxford: Oxford University Press.

Jeanneau, L. (2007) 'Discrimination: Wal-Mart visé,' Alternatives Économiques. (256). [Online] Available at http://www.alternatives-economiques.fr/discrimination---wal-mart-vise_fr_art_ 209_24739.html, [Accessed: 10 April 2014].

Kumar, P. and Schenk, C. (2004) 'Institutional and Conceptual Perspectives on Union Renewal,' Notes for presentation at the CRIMT Colloquium on Union Renewal. November 17-20, Montreal. [Online] Available at http://library.fes.de/pdf-files/gurn/00121.pdf, [Accessed: 10 April 2014].

Kumar, P. and Murray, G. (2006) 'Innovation in Canadian Unions: Patterns, Causes and Consequence,' in Kumar, P. and Schenk, C. (eds.) Paths to Union Renewal: Canadian Experience. Peterborough: Broadview Press.

Laprade, Y. (2013) 'Walmart : une mobilisation syndicale s'organise,' La Presse. April 1. [Online] Available at http://www.lapresse.ca/actualites/national/201303/31/01-4636404-walmart-unemobilisation-syndicale-sorganise.php, [Accessed: 10 April 2014].

Human Right Watch (2007) 'Discounting Rights: Wal-Mart's Violation of US Workers' Right to Freedom of Association,' 19 (2). [Online]. Available at http://www.hrw.org/reports/2007/ 04/30/discounting-rights, [Accessed: 10 April 2014].

Internationaliste (L') (2004) 'Attention travailleurs de Wal-Mart! Une victoire pour la syndicalisation au Québec,' L'Internationaliste. September. [Online] Available at http://www.internationalist. org/walmartquebec0904fr.html, [Accessed: 10 April 2014].

Lichtenstein, N. (ed.) (2006) Wal-Mart. The Face of Twenty-First-Century Capitalism. New York/London: The New Press.

Mayer, S. (2013) Les effets de la libéralisation des marchés sur les conditions de travail et de vie des femmes. Le cas Wal-Mart, Montreal: IEIM Editions.

Messier, M. (2013) 'Notre Walmart: au Québec dès l'automne,' L'Aut'Journal. April. [Online] Available at http://lautjournal.info/default.aspx?page=3\&NewsId=4544, [Accessed: 10 April $2014]$.

Meunier, H. (2013) 'La Presse incognito chez Walmart,' La Presse. April 29. [Online] Available at http://www.lapresse.ca/actualites/national/201304/27/01-4645220-la-presse-incognito-chezwalmart.php, [Accessed: 10 April 2014].

Noiseux, Y. (2008) État, syndicalisme et travail atypique au Québec: une sociologie des absences et des émergences. Doctoral thesis in sociology, University of Quebec in Montreal.

Parent, R. (2008) 'Première convention collective chez Wal-Mart,' La Presse. August 15. [Online] Available at http://affaires.lapresse.ca/economie/200901/06/01-685797-premiere-conventioncollective-chez-wal-mart.php, [Accessed: 10 April 2014]. 
Popu, N. (2010) 'Walmartization and the McJob: The Jobs that Boomed in the New Economy' in Pupo, N., Glenday, D. and Duffy, A. (eds.) The Shifting Landscape of Work. Toronto: Nelson.

Rosen, E.I. (2014) The Globalization of Wal-Mart. London: Workers Press.

Rosen, E.I. (2005) 'Life Inside America's Largest Dysfunctional Family: Working for Wal-Mart,' New Labor Forum. 14(1): 31-39. [Online] Available at http://www.jstor.org/discover/ $10.2307 / 40342519$ ? sid=21105743130133\&uid=70\&uid=2129\&uid=3739448\&uid=2\&uid= 4\&uid=3737720, [Accessed: 17 November 2014].

Sousa Santos, B. de. (2004) 'A Critique of Lazy Reason: Against the Waste of Experience,' in Wallerstein, I. (ed.) The Modern World-System in the Longue Durée. Boulder: Paradigm Publishers.

Statistics Canada (2013a) 'Enquête sur la population active (EPA), estimations selon le Système de classification des industries de l'Amérique du Nord (SCIAN), le sexe et le groupe d'âge, non désaisonnalisées,' Table 282-0007, 2013. [Online] Available at http://www5.statcan.gc.ca/ cansim/a26?lang=fra\&retrLang=fra\&id=2820007\&pattern=epa\&tabMode=dataTable\&srchL an=-1\&p1=1\&p2=-1, [Accessed : 10 April 2014].

Statistics Canada (2013b) Revenu moyen après impôt selon le type de famille économique (2007 à 2011). [Online] Available at http://www.statcan.gc.ca/tables-tableaux/sum-som/102/cst01/ famil21a-fra.htm, [Accessed: 10 April 2014].

TUAC (2014) Au sujet des TUAC au Québec. [Online] Available at http://www.tuacquebec.ca/ index.php/notre-syndicat/au-sujet-des-tuac, [Accessed: 19 December 2014].

(2014) 'Wal-Mart Canada,' Les Affaires. [Online] Available at http://www.lesaffaires.com/fichesentreprise/walmart-/2345, [Accessed: 15 December 2014).

Yates, C. (2004) 'Forum: Reorganizing Unions, Rebuilding the Labor Movement by Organizing the Unorganized: Strategic Considerations,' Studies in Political Economy. (74): 171-179.

Yates, C. (2006) 'Women are Key to Union Renewal: Lessons from the Canadian Labour Movement,' in Kumar, P. and Schenk, C. (eds.) Paths to Union Renewal: Canadian Experience. Peterborough: Broadview Press.

Yates, C. (2011) 'Organizing Women in the Spaces between Home, Work and Community,' Relations industrielles/Industrial Relations. 66(4): 585-603. [Online] Available at: http://web. ebscohost.com.acces.bibl.ulaval.ca/ehost/pdfviewer/pdfviewer?sid=a8ad37b7-6142-431ab85c-47292f9c686a\%40sessionmgr4003\&vid=2\&hid=4209, [Accessed: 10 April 2014].

Zeiler, D. (2013) "How the 'Wal-Mart Syndrome' Pushes Millions More Onto Food Stamps," Money Morning. June 13. [Online] Available at http://moneymorning.com/2013/06/13/howthe-wal-mart-syndrome-pushes-millions-more-onto-food-stamps, [Accessed: 10 April 2014]. 


\section{BIOGRAPHICAL NOTE}

STÉPHANIE MAYER has started in 2012 a PhD in Political Science at Université Laval in Québec, Canada, under the supervision of Diane Lamoureux. Her thesis focuses on the feminist theorizations of heterosexuality. Her fields of interest concern social movements, political subjectivities and feminist theories. She is a member of the Quebec Network of feminist studies (RéQEF).

[Email: stef.mayer@gmail.com]

YANICK NOISEUX is Assistant Professor in the Department of Sociology at Université de Montréal in Québec, Canada. His work focuses on the renewal of trade unionism, the transformation of work and social policy in the context of globalization. Codirector of the interdisciplinary and interuniversity research group on employment, poverty and social protection (GIREPS) and member of the Centre for Studies on Integration and Globalization (CEIM), he's currently conducting research on collective organization on peripheral labor markets in Canada and India.

[Email: yanicknoiseux@gmail.com] 